Environment Conservation Journal 14(3) 95-99, 2013

ISSN 0972-3099 (Print) 2278-5124 (Online)

Abstracted and Indexed

\title{
Water quality profile of fresh water wetland of Atpadi in Sangli District, Maharashtra (India)
}

\author{
Alaka A. Patil \\ Received: 22.08 .2013
}

Revised: 13.10.2013
Accepted: 19.11.2013

\begin{abstract}
This paper presents a study on influence on environmental parameters on water quality at wetland of Atpadi in Atpadi tehsil of Sangli district on the basis of water quality index (WQI). WQI was determined on the basis of various parameters like pH, dissolved oxygen, total alkalinity, total hardness, calcium, magnesium, chlorides, total dissolved solids and biological oxygen demand for which no earlier reports are available on these water bodies. During this investigation, it was observed that some parameters are within the range prescribed by World Health Organization, Indian Council of Medical Research, Bureau of Indian Standard etc. But some parameters are beyond the permissible limit.
\end{abstract}

Keyword: Fresh water wetland, Atpadi reservoir, WQI, Sangli district, Maharashtra

\section{Introduction}

Fresh water has become a scarce commodity due to over exploitation and pollution of water. Increasing population and its necessities has lead to the deterioration of surface and subsurface water.Water and life are two sides of the same coin. Life initiates and grows in the lap of water. Water is very vital to all forms of lives from very small organisms to very complex systems of plants, animals and human being. The purity of water varies from place to place in nature. Water Quality Index (WQI) is one of the most effective tools to communicate information on the quality of water to concerned citizens and policy makers (WHO 1993, APHA 1992). The WQI evaluates the values to each water quality parameter relative to its objective value. WQI is based on some important parameters that can provide a simple indicator of water quality. It gives the public a general idea of the possible problems with water in a particular region. Nine parameters were taken for WQI calculations namely, $\mathrm{pH}$, dissolved oxygen, total alkalinity, total hardness, calcium, magnesium, chlorides, total dissolved solides and biological oxygen demand. The water quality index is unitless single dimensional number between 0 and 100 .

\section{Author's Address}

Department of Botany, Padmabhushan Dr. Vasantraodada Patil Mahavidyalaya, Tasgaon, Dist: Sangli Maharashtra, India Email: patilalka2@yahoo.com

\section{Material and methods Study area}

The fresh water wetland of Atpadi of Atpadi Tehsil is located in Sangli district $\left(74^{\circ} 37^{\prime} \mathrm{N}\right.$ latitude and $17^{\mathrm{O}} 19^{\prime}$ E longitude) of southeastern Maharashtra in India. A year can be broadly divided into three seasons; summer season from March to May, rainy season from June to October and winter from November to February.

\section{Morphometry of Wetland}

The total capacity of storage is $309.09 \mathrm{Mcft}$ and dead storage is $27.15 \mathrm{Mcft}$. The catchment area of reservoir is $204.8 \mathrm{~km}$. Total length of dam including slipway is $1068 \mathrm{M}$ with $323 \mathrm{M}$ is only the length of slipway. It is of clear overflow type. Earthen type of dam having height of $16.50 \mathrm{M}$. Total water spread is 11.16 hectare having 36 hectare of submergence area. The bottom of wetland is rocky hence aquatic macrophytes are poorly developed. 1959 to 1969 was the duration of reservoir construction. The water is formerly used for irrigation but also for washing, bathing and pisciculture activities. The wetland stores rain water received from adjoining catchment area and is much influenced by anthropogenic activities. The sampling sites were selected by considering the inflow, outflow and anthropogenic activities. Three sampling sites for wetland were selected for 
monthly analysis. The water samples were collected approximately 10-15 meters from border line of wetland in pre-cleaned five liter plastic cans and immediately brought to the laboratory for various physico-chemical analysis. Therefore, sampling sites were constant through out the annum.The calculation of WQI was made using weighted arithmetic index method. (Brown et al., 1970 and 1972) as follows.

\section{Water quality index}

In lakes the pollution increases through surface run off and precipitation of chemical pollutants of industry, domestic and agriculture. Anthropogenic activities are one of the important factors of pollution. Hortton (1965) proposed that first WQI and classification of WQI by considering various water bodies.For calculations of WQI, selection of parameters has great importance which widens the quality index. Nine physico chemical parameters namely $\mathrm{pH}$, dissolved oxygen (DO), total alkalinity, total hardness, calcium, magnesium, chlorides, total dissolved solids (TDS) and biological oxygen demand (BOD) were used to calculate WQI.

\section{Calculations of quality rating $\left(\mathbf{q}_{\mathbf{n}}\right)$}

Let there be $n$, water quality parameters and quality rating $\left(\mathrm{q}_{\mathrm{n}}\right)$ corresponding to $\mathrm{n}^{\text {th }}$ parameter is a number reflecting the relative value of this parameter in the polluted water with respect to its standard permissible value. The $\mathrm{q}_{\mathrm{n}}$ is calculated by using the following expression-

Where,

$$
\mathrm{Q}_{\mathrm{n}}=100\left(\mathrm{~V}_{\mathrm{n}}-\mathrm{V}_{10}\right) /\left(\mathrm{S}_{\mathrm{n}}-\mathrm{V}_{10}\right)
$$

$\mathrm{Q}_{\mathrm{n}}=$ Quality rating for the $\mathrm{n}^{\text {th }}$ water quality parameter.

$\mathrm{V}_{\mathrm{n}}=$ estimated value of $\mathrm{n}^{\text {th }}$ parameter at a given sampling stations.

$\mathrm{S}_{\mathrm{n}}=$ standard permissible value of $\mathrm{n}^{\text {th }}$ parameter

$\mathrm{V}_{10}=$ ideal value of $\mathrm{n}^{\text {th }}$ parameter in pure water.

All the ideal values $\mathrm{n}^{\text {th }}$ parameter $\left(\mathrm{V}_{10}\right)$ are taken as zero for the drinking water except for $\mathrm{pH}=7.0$ and dissolved oxygen $=14.6 \mathrm{mg} / \mathrm{L}$.

\section{Calculation of quality rating for $\mathbf{p H}$}

For, $\mathrm{pH}$, ideal value is 7.0 (neutral water) and permissible value is 8.20 . Therefore, quality rating for $\mathrm{pH}$ is calculated from following relation,

$$
\mathrm{q}_{\mathrm{pH}}=100\left[\left(\mathrm{~V}_{\mathrm{pH}^{-}} 7.0\right),(8.20-7.0)\right]
$$

Where, $\mathrm{V}_{\mathrm{pH}}=$ observed value of $\mathrm{pH}$.

\section{Calculation of quality rating for dissolved} oxygen

The ideal value is for dissolved oxygen is 14.6 $\mathrm{mg} / \mathrm{L}$. and standard permissible value for drinking water is $5 \mathrm{mg} / \mathrm{L}$. Therefore, quality rating is calculated from following relation,

$$
\mathrm{q}_{\mathrm{DO}}=100\left[\left(\mathrm{~V}_{\mathrm{DO}^{-}}-14.6\right),(5-14.6)\right]
$$

Where, $\mathrm{V}_{\mathrm{DO}}=$ measured value of dissolved oxygen .

\section{Calculation of unit weight $\left(\mathbf{W}_{\mathrm{n}}\right)$}

The unit weights $\left(\mathrm{W}_{\mathrm{n}}\right)$ for various water quality parameters are inversely proportional to the recommended standards for the corresponding parameters.

$$
\begin{aligned}
& \mathrm{W}_{\mathrm{n}}=\mathrm{K} \backslash \mathrm{S}_{\mathrm{n}} \\
& \text { Where, } \mathrm{W}_{\mathrm{n}}=\text { unit weight for } \mathrm{n}^{\text {th }} \text { parameters, } \\
& \mathrm{S}_{\mathrm{n}}=\text { standard value } \mathrm{n}^{\text {th }} \text { parameters. } \\
& \mathrm{K}=\text { constant for proportionality }
\end{aligned}
$$

\section{Calculation of WQI}

WQI is calculated from the following equation

$$
\mathrm{WQI}=\sum \mathrm{q}_{\mathrm{n}} \mathrm{W}_{\mathrm{n}} / \sum \mathrm{w}_{\mathrm{n}}
$$

\section{Results and Disscussion}

The average values of Atpadi wetland of various parameters are used for WQI calculations and depicted in Table 1. The average $\mathrm{pH}$ of reservoir was 8.0 during August and 9.17 during May. The values of $\mathrm{pH}$ remained alkaline throughout the study period. But the annual fluctuations were negligible, indicating good buffering capacity. According to WHO (1993) the desirable $\mathrm{pH}$ of drinking water is 7.0 to 8.5 . The water $\mathrm{pH}$ ranging between 6.5 to 9.0 at daybreak is most suitable for better aquaculture (Jhingran 1982). In the present work the highest values of $\mathrm{pH}$ during summer may possibly be due to removal of sufficient amount of $\mathrm{CO}_{2}$ by photosynthetic process of the aquatic system. (Solanki et al. 2005, Kaur et al. 1997). It is interesting here to note that, dissolved oxygen rises appreciably during summer and decreases in monsoon months. However, very little variation was observed during summer and monsoon. The amount of dissolved oxygen was $4.21 \mathrm{mg} / \mathrm{l}$ in August and $8.55 \mathrm{mg} / \mathrm{l}$ in May. The minimum dissolved oxygen limit for fish growth is $4.0 \mathrm{mg} / \mathrm{l}$ (Jhingran 1982). 
Table 1 WQI Calculation of Atpadi wetland by considering mean values of year Aug. 2010 to July 2011

\begin{tabular}{|c|l|c|c|c|c|c|}
\hline $\begin{array}{c}\text { Sr. } \\
\text { No. }\end{array}$ & \multicolumn{1}{|c|}{ Parameters } & $\begin{array}{c}\text { Standard } \\
\text { Values }(\mathbf{S n})\end{array}$ & $\mathbf{1 / S n}$ & $\begin{array}{c}\text { Unit weight } \\
(\mathbf{W n})\end{array}$ & $\begin{array}{c}\text { Observed } \\
\text { Values }\end{array}$ & $\begin{array}{c}\text { Quality rating } \\
(\mathbf{q n})\end{array}$ \\
\hline 1. & $\mathbf{p H}$ & 7 & 0.143 & 0.236 & 8.46 & 97.333 \\
\hline 2. & Dissolved Oxygen & 5 & 0.200 & 0.330 & 6.44 & 84.000 \\
\hline 3. & Total Alkalinity & 120 & 0.008 & 0.014 & 310.168 & 258.473 \\
\hline 4. & Total Hardness & 500 & 0.002 & 0.003 & 265.945 & 53.189 \\
\hline 5. & Calcium & 75 & 0.013 & 0.022 & 45.157 & 60.209 \\
\hline 6. & Magnesium & 30 & 0.033 & 0.055 & 20.128 & 67.093 \\
\hline 7. & Chlorides & 250 & 0.004 & 0.007 & 44.248 & 17.699 \\
\hline 8. & Total Dissolved Solids & 500 & 0.002 & 0.003 & 398.666 & 79.733 \\
\hline 9. & $\begin{array}{l}\text { Biological Oxygen } \\
\text { Demand }\end{array}$ & 5 & 0.200 & 0.330 & 3.017 & 60.340 \\
\hline
\end{tabular}

\section{*Except $\mathrm{pH}$ all values are expressed as $\mathrm{mg} / \mathrm{l}$}

According to APHA (1992) the lowest dissolved oxygen for maintaining fish in healthy condition is $5.0 \mathrm{mg} / \mathrm{l}$ and the critical value is $3.0 \mathrm{mg} / \mathrm{l}$. In present study the range of dissolved oxygen was found optimum for fish growth. Relatively higher values of dissolved oxygen during summer probably as a result of photosynthetic activity (Solanki et al. 2007). Similar type of observation was made by Khare et al. (2007).

The range of total alkalinity varied from 150.33 $\mathrm{mg} / \mathrm{l}$ to $476 \mathrm{mg} / \mathrm{l}$. Alkalinity reduced in monsoon and increased in summer.Many workers have observed similar pattern of variation in total alkalinity which support present findings (Shrivastava 2005, Hujare 2008, Sukhija 2007, Sharma and Jain 2000, Chatterjee and De 2008, Raveen et al. 2008).

Moyle (1949) have classified water into nutrient status based on alkalinity as follows,

$\begin{array}{ll}1 \text { to } 15 \mathrm{mg} / \mathrm{l} & \text { nutrient poor } \\ 16 \text { to } 60 \mathrm{mg} / \mathrm{l} & \text { moderately rich } \\ \text { More than } 60 \mathrm{mg} / \mathrm{l} & \text { nutrient rich }\end{array}$

Based on the above classification the reservoir show nutrient rich status. Hardness values were recorded within $223 \mathrm{mg} / \mathrm{l}$ in the month of December to $329.67 \mathrm{mg} / \mathrm{l}$ in May. Definite pattern of seasonal variation was noticed i. e. maximum during summer and minimum was noticed during winter. Hujare and Mule (2008) and Pundhir and Rana (2002) have also noticed maximum hardness in summer and minimum in winter. Calcium content of Atpadi reservoir ranged between 31.88 $\mathrm{mg} / \mathrm{l}$ to $52.89 \mathrm{mg} / \mathrm{l}$. Calcium content was found minimum during winter and maximize in summer. Subhashini and Saradhamani (2005) have recorded similar pattern of change in calcium content.The concentration of magnesium in Atpadi reservoir varied from $16.31 \mathrm{mg} / \mathrm{l}$ to $25.82 \mathrm{mg} / \mathrm{l}$. Maximum magnesium content was observed in summer season. The concentration of magnesium was minimum than concentration of calcium possibly due to lesser occurrence of magnesium minerals in bottom strata of reservoir. According to WHO (1993) and BIS (1991) the permissible limit for magnesium content in drinking water is $50 \mathrm{mg} / \mathrm{l}$. The present results of reservoirs are within the permissible limit. Sobha and Harilal (2005) have recorded similar observation at Ampalthara. Similar pattern of changes were also recorded by Khare et al. (2007), Subhashini and Saradhamani (2005).The content of chloride for Atpadi wetland was $36.5 \mathrm{mg} / \mathrm{l}$ in December and $52.79 \mathrm{mg} / \mathrm{l}$ in May. In present investigation, chloride values were found increased during summer and decreased in winter. According to WHO (1993) and BIS (1991) permissible limit of chloride is $200 \mathrm{mg} / \mathrm{l}$ for drinking water. The water from the reservoir was below limit. Therefore, it is noted that the water is 
fit for drinking. The chloride concentration reached maximum during summer, as the level of reservoir attained low level. However, this may be one of the reasons the values decreased steadily through monsoon and reached minimum in winter due to dilution. Similar condition was observed by Anand and Sharma (2000), Vijay Kumar et al. (2005) and Khare et al. (2007).The amount of total dissolved solids detected from water samples at Atpadi were $275 \mathrm{mg} / \mathrm{l}$ and $603 \mathrm{mg} / \mathrm{l}$.

Table 2 WQI as per Bhargava (1989)

\begin{tabular}{|l|l|}
\hline \multicolumn{1}{|c|}{ WQI Values } & \multicolumn{1}{c|}{ Classification } \\
\hline $90>$ & Excellent \\
\hline 65 to 89 & Permissible \\
\hline 39 to 64 & Marginally Suitable \\
\hline 11 to 34 & Inadequate for use \\
\hline $0<$ & Totally unsuitable \\
\hline
\end{tabular}

There was steep fall in total dissolved solids values during winter season, while content increased during summer. Rincy and Tessy (2010) and Shrivastava and Alam (2007) have observed higher concentration of total dissolved solids during premonsoon season. Sukhija (2007) has recorded minimum total dissolved solids values during December. Biochemical oxygen demand at Atpadi reservoir was $2.103 \mathrm{mg} / \mathrm{l}$ and $3.787 \mathrm{mg} / \mathrm{l}$. Minimum BOD values were observed during December and maximum during May. Similar fluctuations in BOD values were reported by Subhashini and Saradhamani (2005), Vijay Kumar et al. (2005) and Chatterjee and De (2008). WHO (1993) specify that the drinking water should be devoid of BOD. Accordingly the present values for reservoir suggested the contaminating status. It may be due to human and cattle activities in and around the reservoirs. Singh and Gupta (2004), Raghuwanshi (2005), Sudeep et al. (2008) and Agrawal et al. (2004) explained that, the highest values of BOD during summer were attributed to biological activity, due to high organic decomposition during summer. In winter, microbial activity lowers hence values of BOD decreases.
Table 3 WQI as per Abbasi (2002)

\begin{tabular}{|c|c|c|}
\hline WQI & Description & Class \\
\hline $63-100$ & Good to Excellent & $\mathrm{A}$ \\
\hline $50-63$ & Good & B \\
\hline $38-50$ & Bad & C \\
\hline 38 & Very Bad & D,E \\
\hline
\end{tabular}

\section{Conclusion}

According to Bhargava (1989) classification of WQI, the water of Atpadi wetland is in permissible category. As per Classification of Abbasi (2002) the wetland water is good to excellent indicating pollution less water for local inhabitants.

\section{Acknowledgement}

Author is thankful to Dr. R. R. Kumbhar, Principal, P.D.V.P. Mahavidyalaya, Tasgaon, Dist: Sangli (MS) for encouragement and providing necessary facilities to carry out the work.

\section{References}

Abbasi, S.A. 2002. Water Quality Indices State-of-the-Art, Pondicherry Pondicherry University, Centre for Pollution Control \& Energy Technology.

Agrawal Manisha, Desmukh and Kanchan M.C. 2004. Studies on physico-chemical variation in 'Pani ki Dharmshala' reservoir, Jhansi, India. Eco. Env. and Cons.10 (3):287-284.

APHA 1992. Standard methodS for the Examination of water and waste water. $18^{\text {th }}$ edition American Public Health Association, Washington. DC.

Anand V.K. and Sharma S. 2000. Physico-chemical characteristics of the bottom sediment of Lacustrine Habitats of Jammu II. Lake Mansar: Ecol. Env and Cons.6 (4):419-428.

Bhargava, D.S. 1989. "Expression for Drinking Water Supply Standards, "ASCE, 111: 304-317.

BIS 1991. Specifications for drinking water IS: 10500:1991. Bureau of Indian Standard institution, New Delhi.

Brown, R.M., McClelland N.I., Deininger R.A. and Ronald G.T. 1970.A Water Quality Index - Do We Dare? Water Sewage Works, 11: 339-349.

Brown, R.M., McCleiland N. J., Deininger, R.A., Connor O, and M.F. 1972. A water Quality Index -Crossing the 
psychological barrier, Jenkis, S.H. (ed.) Proc. Int. Conf. on Water Poll. Res. Jerusalem, 6; pp. 187-197.

Chaterjee C. and De A. 2008. Impact of Anthropogenic activitieson drinking water quality: A case study of Raniganj coalfield area (W.B) Nature, Environment and Pollution Technology: 7(3:) 451-459.

Horton, R.K. 1965. An Index Number System for Rating Water Quality, J. Water Pollution Control Administration, 37: pp.3000.

Hujare M. S. 2008. Limmnological studies of the perennial water body Attigre tank Kolhapur district (Maharashtra). Nature, Environment and pollution Technology: 7(1): 43-48.

Hujare M. S. and Mule M.B. 2008. Seasonal variation of physico - chemical parameters in the perennial tank of Talsande, Maharashtra. J. Ecotoxicol, Environ monit 18(3): 233-242.

ICMR 1975. Manual of standards of quality for drinking water supplies. Indian Council of Medical Research.

Jhingran V. G. 1982. Fish and Fisheries of India. Hindustan Publishing corp, (India) Delhi.

Kaur H, Dhillon S. S., Bath K. S. and Mandar G. 1997. Interrelationships between physico-chemical factors at Harike wetland (Punjab-India). Journal of Environment and pollution 4 (3): 237-240.

Khare S. L., Paul S.R. and Dubey A. 2007. A study on water quality of Khomph- Niwari lake at Chhatarpur, M.P. Nature, Env. and Pollu. Tech.: 6(3): 539-540.

Moyle J. B. 1949. Some indices of lake productivity. Trans. Amer. Fish. Soc. 76. 322-334.

Pundhir P. and Rana K. S. 2002. Pollution dynamics of phytoplankton in the wetland area of Keoladeo National Park, Bharapur (Rajsthan). Eco. Env. and Cons.8(3):253-235.

Raghuwanshi A. K. 2005. The impact of physico-chemical parameters of lower lake of Bhopal on the productivity of Eichhornia crassipes: Eco.Env.and Cons.11 (34):333-336.

Shrivastava B.and Allam M. 2007. Studies on physicochemical characteristics and heavy metals in Kelo river along city Stretch in Raigarh, Chattisgarh. Nature Env. And Pollu. Tech. 6(4): 609 -613.
Singh M. and Gupta K.C. 2004. Physico-chemical studies of Water of river Yamuna at Mathura: Eco. Env and Cons.10 (2):193-196.

Sobha V. and Harilal C. 2005. Influence of changing water quality on Eicchornia crassipes (Mart) Solms. In the uptake pattern of various minerals and nutrients: Ecol. Env and cons 12 (1):1-6.

Solanki S., Rana K. S. and Singh A. K. 2005. Study of the physico-chemical characteristics of Khara Nadi water, Agra. Fundamentals of Limnology edited by Arvindkumar. 182-190.

Solanki V.R., Murthy S. S., Amarjit Kour and Sabita Raja S. 2007.Variation in dissolved oxygen and biochemical oxygen demand in two fresh water lakes of Bodhan,Andhra Pradesh, India. Nature Env. and Pollu. Tech. 6(4) 623-628.

Subhashini S. and Saradhamani N. 2005. Hydrobiology of Aliyer reservoir, Coimbatore district, India. Fundamentals of Limnology edited by Arvindkumar. 56-60.

Sudeep B.M., Srikantaswamy S. and Hosmani S. P. 2008. The study of phytoplankton dynamics in two lakes of Mysor,Karnataka state, India.: Nature, Environment and Pollution Technlogy:7(4):697- 702.

Sukhija L. 2007. Seasonal variation in zooplanktonpopulation in relation to physico-chemical characteristics of water in Kayad lake near Ajmer,Rajsthan: Nature, Environment and pollution Technology. 6(2)299-302.

Raveen R., Chennakrishnan C. and Stephen A. 2008. Impact of pollution on the quality of water in three fresh water lakes of Suburban,Chennai. Nature Environment and pollution Technology: 7(1) 61-64.

Rincy J. and Tessy P. P. 2010. Water quality and pollution status of Chalakudy River at KathiKudam, Thrissur District, Kerala, India. Nature, Environment and Pollution Technlogy:9(1):113-118.

Vijaykumar K., Shashikantha M., Mural J. and Vasanth Kumar B. 2005. Pollution status of Bhima river at Gulbarga: Ecol. Env and cons 11 (3-4):467-469.

W.H.O. 1993. Guidelines for drinking water quality (vol.2): Recommendations. World Health Organization, Geneva. 